\title{
SUPERVISION OF PRODUCTION OF METAL ROOF TILES
}

\author{
Stanisław Płaska, Radosław Cechowicz, Piotr Wolszczak
}

\begin{abstract}
S u m mary
This paper presents the characteristic of the production of sheet metal roofing tiles. The basic problem affecting the quality of the product was identified to be the repeatability of the metal sheet positioning and the cross ribbing. A measurement and control system was proposed for controlling the movement of the metal sheet and to automatically correct positioning errors. Presented results illustrate the effects of the solutions in the industrial environment.

Keywords: positioning error, process monitoring, corrective action, automation
\end{abstract}

\section{Nadzorowanie procesu produkcji blachodachówki}

$$
\text { Streszczenie }
$$

W pracy przedstawiono charakterystykę produkcji pokryć dachowych z blachy - blachodachówki. Wskazano podstawowe kryterium oceny jakości wyrobów: uzyskanie powtarzalności podziałki przetłoczeń poprzecznych. Przedstawiono rozwiązania układu do pomiaru przemieszczenia podawanej blachy, pomiaru podziałki przetłoczeń oraz rozwiązania automatycznego korygowania błędów pozycjonowania i nadzorowania linii wytwórczej. Przeprowadzono analizę efektów zastosowanych rozwiązań w warunkach przemysłowych.

Słowa kluczowe: pozycjonowanie, błąd pozycjonowania, monitoring procesu, działania zaradcze, automatyzacja

\section{Introduction}

The metal roofing sheets are manufactured in automated production lines. The sheets come in standard widths, the customer specifies the length of individual sheets according to their planned location on the roof. Pre-processed (standard width, covered with paint and protective foils) cold-rolled sheets used for production are available at the market. During the production process, the metal sheet is passed through the set of several forming rolls which form the cross profile of the roof tile. The metal sheet, loaded onto the feeder, is unrolled automatically during the process. The feeder is a universal, autonomous device, that can be used with any forming machine. The forming rolls are synchronized

\footnotetext{
Address: Prof. Stanisław PŁASKA, Radosław CECHOWICZ, PhD Eng., Piotr WOLSZCZAK, $\mathrm{PhD}$ Eng., Faculty of Mechanical Engineering, Lublin University of Technology, Nadbystrzycka str., 20-816 Lublin, Poland, E-mail: wm.ka@pollub.pl
} 
by the chain transmission and driven by the inverter-controlled electric motor. The sheet is passed through the forming rolls at constant speed. Then, the sheet is stopped and the transversal step is formed in a die press. The process is repeated every segment size (typically 350 or $400 \mathrm{~mm}$ ). Finally, the roof tile is cut off in the guillotine, mounted immediately after the die press.

One of the critical quality characteristics of roof tiles is the distribution of segment length (the differences in distance between successive transverse ribbing). The quality of the formation of the ribbing depends on several factors, of which the most important are the accuracy and repeatability of positioning of the metal sheet in the machine and repeatability of the die-pressing. The distribution of the distances between the ribs limits the maximum length of the roof tile that can be made on the machine and defines the quality of the product. Figure 1 shows one rib of several sheets of roof tiles stacked on each other. In the picture one can see that the distance between successive ribs are slightly different. This illustrates a spread in segment length. Excessive spread disqualifies the product.

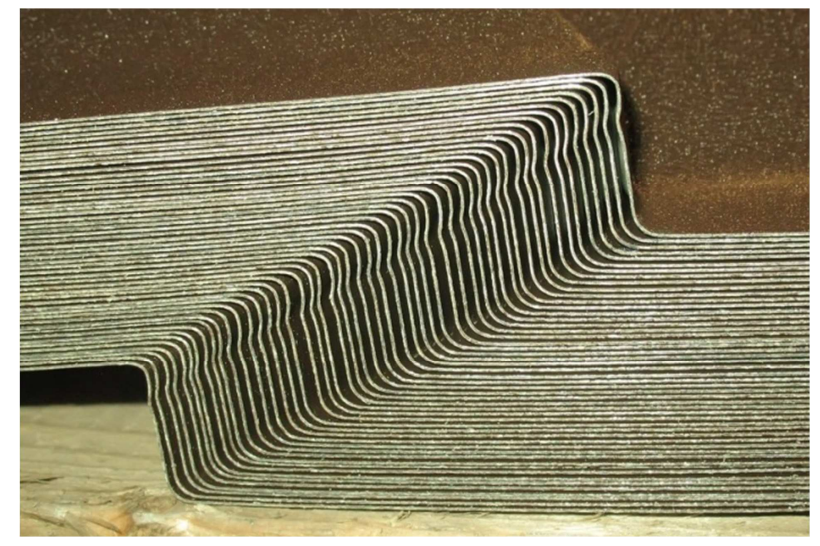

Fig. 1. Steel roofing tiles stacked for transportation, and the view of one of the ribs

To keep the segment length to tolerance, it is necessary to monitor and supervise the production process. In the current practice, the monitoring is accidental. To check the quality of the product, manufacturers carry out an occasional, trial assembly of roofs in the production hall, simulating the assembly on the roof. Test assembly allows to visual check for possible deviations in the alignment of the sheets. Where meaningful irregularities are found, corrective actions shall be taken involving the check of the chain transmission system, and deleting excessive mechanical backlash. However, such measures are only effective if there is noise associated with the mechanical 
drive system. They do not eliminate the risk of making defective products. Furthermore, the production process is stopped at the time of the test and during the corrective actions. In the result, the procedure is cumbersome and expensive.

One of the method used to improve the accuracy of the metal sheet forming is the modification of the die press. In one of the solution, documented in patent [1], the length of the die was extended to cover full module (distance between two ribs) or its multiplication. The metal sheet is held by the die. However, the solution has at least two major disadvantages: high cost of the dies (due to the size) and restricting the machine capabilities to just one module length, which contrasts with modern machine building trends. On the other hand, universal machines, like the one documented in the patent [2], do not have any features that could improve the accuracy of the ribbing. The solution depicted in the patent [3] is capable to achieve good accuracy of the die-pressing without compromising the process flexibility (the machine is capable of making products with different modules). In this solution there are two pairs of dies, first of them is used for holding the metal sheet in place, and the other pair actually forms the rib. It was shown in our research that such an arrangement allows substantial improvement in the accuracy and repeatability of die-pressing. The solution is however, more expensive than the classic design with one pair of dies, as it requires using additional actuators and an extra pair of dies.

A general rule in metal sheet forming is to fix the material in place to prevent an uncontrollable movement during the process. For example, in the patent [4], the metal sheet is held by a special, U-shaped fold at the edge of the form. This particular solution cannot be used in metal roofing covers (as it would negatively impact the presentation and the function of the product), but the idea is appropriete. Various methods of sheet metal forming process design are outlined in the work [5]. The technological aspects of the sheet metal forming are depicted in the work [6].

The solution presented in this paper contains an automated method of monitoring of the production process and correcting it without the need for test assembly. The first step in this approach was to develop a simple system for measuring the displacement of the material in the machine, which would allow for evaluation of its positioning. In the second step, a system for evaluation of the distribution of the ribbing distances was developed and implemented. In the third, final step, a control system was developed and implemented.

\section{Measuring displacement of the material}

Schematic of the measurement system is shown in Fig. 2. To measure the position of the metal sheet (the material), the incremental rotary encoder was used, which was connected to the hardware counter in the PLC. The real (hardware) resolution of the measurement system was $0.065 \mathrm{~mm}$. An important 
factor in determining the dynamics of the measuring system was the counter sampling time (the time between successive readings of the meter by the PLC program), which was approximately $30 \mathrm{~ms}$.

Measurement control program was written in ladder logic. The program used standard procedures for communication with the counter [7].

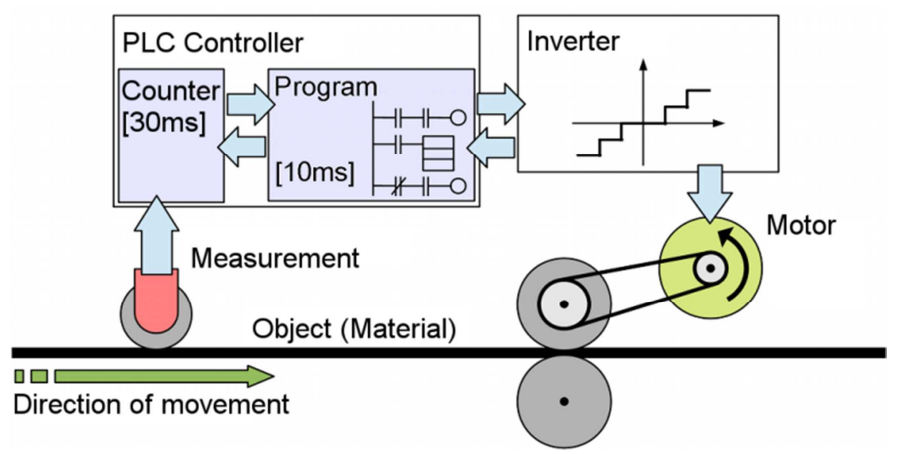

Fig. 2. Diagram of the control circuit, sampling times in brackets [8]

The communication process between the controller and the counter was arranged as shown in Fig. 3 and is described in detail in [8]. To read the current value of the counter, the controller sent a request (REQ). In response to the request bit, the current counter value was written to the buffer and the ready bit was set (RDY=1). The buffer could then be read by the PLC, after that, the ready bit was reset (RDY=0). At the same time the request bit was reset (REQ) and next reading could start. One counter reading operation lasted three PLC cycles which was about $30 \mathrm{~ms}$.

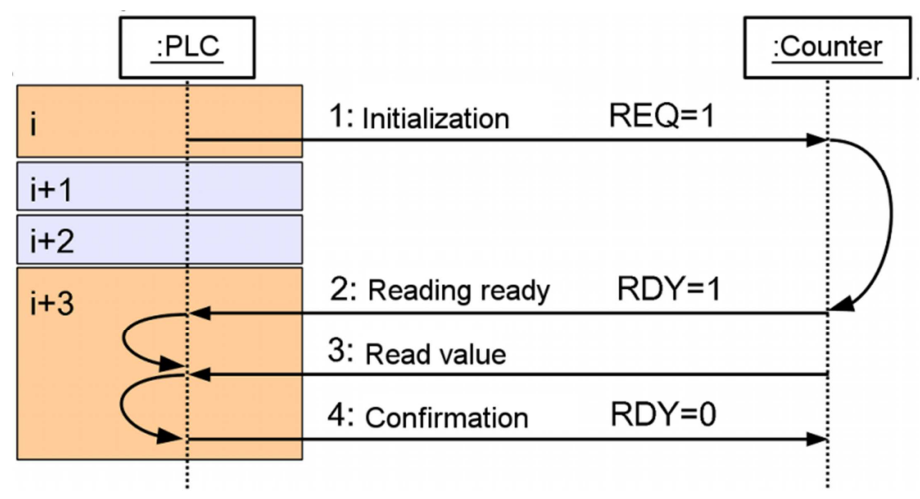

Fig. 3. Sequence diagram for the process of reading the current value of the counter [8] 


\section{Correction of the distance between ribs}

A PLC program was developed to correct the length of the segment (distance between ribs). The program was reading data from an external, optical measurement system and could correct the positioning and forming errors automatically. However, due to high variety of the materials and memory limits in the PLC, the system was mainly used in manual mode, where the corrections to the process had to be accepted by the operator before they could be applied.

Information about the current position of the material was supplied by the encoder as shown in Fig. 2. A predictive, proportional controller was designed for the material positioning process. The outline of the algorithm is shown in Fig. 4.

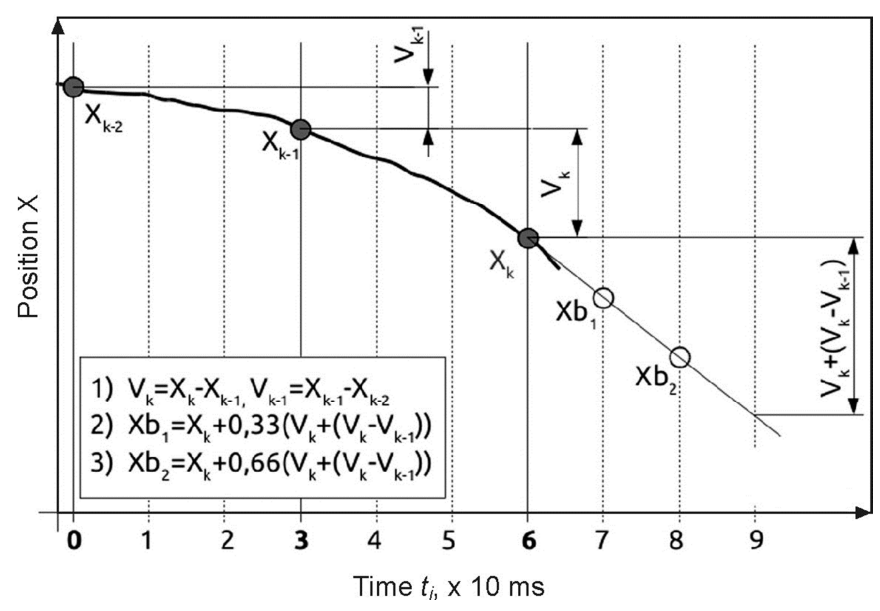

Fig. 4. Outline of the prediction algorithm to evaluate the position of the object

The purpose of the external, optical measurement system was to measure the error resulting from factors other than metal sheet positioning, like die process, misalignment, etc. which were hard to measure by other means (Fig. 5). The process monitoring included: the presentation of the results of positioning in the form of control charts X/R and EWMA/R, histograms, and the control chart for attributes of type $\mathrm{C}$ [9].

One cause of the positioning error was systematic, and was caused by inertia, a change in friction between the metal surface and the surface of the forming rolls (variable thickness, type of paint, protective films, etc.). The other source of error was the mechanical wear of the machine parts (especially drive and stamping parts). The control system could suggest actions to restore a minimum level of technical efficiency of the machine actuators (Fig. 5). In this 
article we merely identify the major classes of distortions and evaluate their impact on the positioning effect as described in $[10,11]$. Due to the high workload on the machine, a functionality of automatic correction of the systematic error was implemented and could be switched on by the operator. The feature could be used to correct the set points of the positioning process like deceleration distance, coasting speed and process mean value shift. These values needed to be changed periodically because of time (drift), air temperature (affecting some parameters like oil density, forces in the forming rolls, etc.), material (sheet thickness, coatings, sheet material) and friction (e.g. in forming rolls) fluctuations.

a)

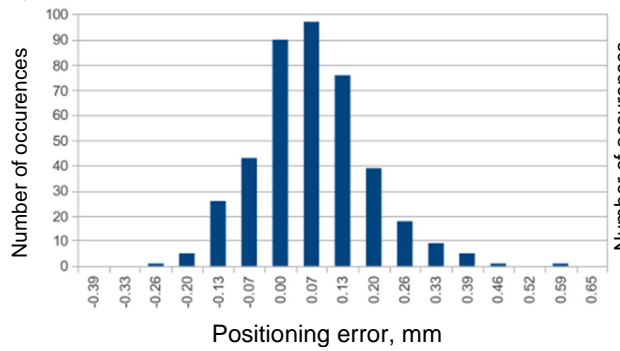

b)

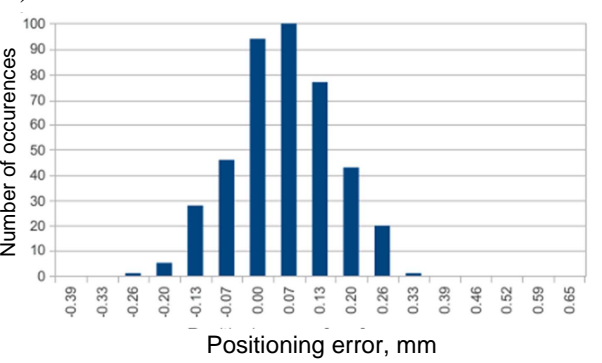

Fig. 5. Positioning error histograms for the metal sheet position before (a) and after (b) automatic correction

\section{Verification of the segment length}

A vision system was used to verify the length of the made segment. The camera was mounted in a location which allowed the direct measurement of the length of the segment between two consecutive ribs.

The system recorded the edge position of the rib. The system accuracy error (optical) was $0.028 \mathrm{~mm}$. The standard deviation obtained from $N=490$ test measurements was $\sigma=0.12 \mathrm{~mm}$. The actual distribution of segments lengths turned out to be greater than the value determined at the stage of positioning (measured with the position encoder). The difference resulted from disturbances that appeared after the positioning - that is, during the die forming process [7]. This additional error could not therefore be neither predicted, nor corrected during the sheet positioning stage. Finally, taking into account all the errors that appeared in the process of production, the implemented control method enables the production of roofing sheets with a segment tolerance value not exceeding Tc $6 \sigma=0.72 \mathrm{~mm}$.

Based on the information gathered during the research, an automatic procedure for documenting the process quality was proposed comprising: a control chart $\mathrm{X} / \mathrm{R}$, the histogram, the calculation of process capability index 
$C_{p k}$ and a report generator documenting the quality of the batch. This documentation, in accordance with the requirements of BS EN ISO9001, could be printed out or sent to the electronic archive.

The histograms and $\mathrm{X} / \mathrm{R}$ chars for the length of the segment, that were obtained from the vision system during the test run are presented in Fig. 6.
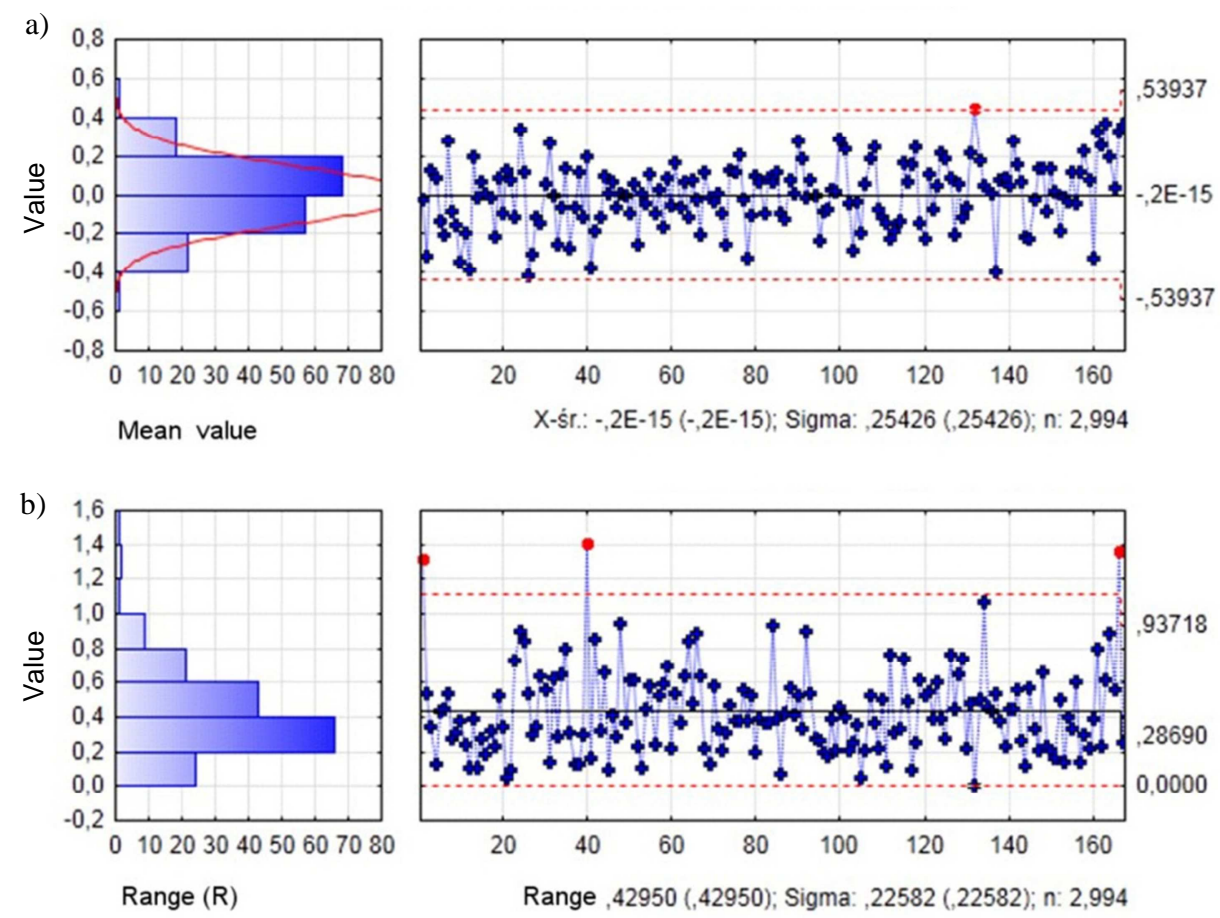

Fig. 6. X/R charts obtained from the optical measurements of the formed (post-production) steel roofing tile module for: $a$ ) mean value, $b$ ) $R$ value

The proposed correction method can be used effectively to correct the effects of low to medium noise. In the case of significant disturbances to the process, like excessive slack in the chain transmission, the positioning time will increase beyond acceptable limits, bringing the production rate to a very low level. In such case, corrective actions must be taken by the service personnel.

\section{Summary}

The proposed (and implemented) system for monitoring and correction of sheet positioning error could stabilize the segment length of the roof tiling and provide the operator with valuable information about the process. The quality of 
the product could then be maintained and kept at the constant level. As the quality of the product could now be estimated (and verified - in the case of the system with the vision system), no other quality check operations were required (including the costly test assembly). The implemented control chart allowed the estimation of the process central value and the estimation of the random error attributed to the mechanical slack in the drive train. The evaluation machine capability performed for each of the machines in the manufacturing system, could provide valuable information for the business management system. It would help in production planning (by assigning more demanding products to machines with higher capabilities) and in making business decisions (like buying a new machine). The documentation provided by the system could also be used for the promotion of the products. The immediate effect for the production floor would be the rationalization of production plans and eliminating the need for expensive checks of finished products.

\section{References}

[1] R.B. NORGATE: Manufacture of roofing or cladding tiles. U.S. Patent No. US4444037 A-1984.

[2] P. SAARENKO: Apparatus for manufacturing roofing or cladding panels. U.S. Patent No. US6289707 B1-2001.

[3] E.G. KING: Apparatus and method for forming steps in profiled sheets of material. U.S. Patent No. US4250728 A-1981.

[4] R.E. ROPER and G.A. WEBB: Urządzenie do hydraulicznego kształtowania części z blachy. U.S. Patent No. PL172554 B1 (1997), p. 25.

[5] R. ARRIEUX, J. GRONOSTAJSKI, Z. GRONOSTAJSKI, A. MATUSZAK, A. NIECHAJOWICZ, Z. ZIMNIAK: Metody projektowania procesów kształtowania blach. Obróbka Plastyczna Metali, 12(2001)3, 23-34.

[6] J. GRONOSTAJSKI: Inteligentny system do dokładnego kształtowania wyrobów z blach. Obróbka Plastyczna Metali, 16(2005)3, 25-35.

[7] S. PLASKA, R. CECHOWICZ, P. WOLSZCZAK: Raport realizacji usługi w ramach umowy NN/91/2012, Politechnika Lubelska, Lublin 2012.

[8] R. CECHOWICZ: Realizacja algorytmu szybkiego pozycjonowania na platformie PLC. Pomiary, Automatyka, Robotyka, 16(2012)10, 54-57.

[9] S. PŁASKA: Wprowadzenie do statystycznego sterowania procesami technologicznymi, Wydawnictwo Politechniki Lubelskiej, Lublin 2000.

[10] P. TUREK, W. KWAŚNY, J. JĘDRZEJEWSKI: Zaawansowane metody identyfikacji błędów obrabiarek. IM Inżynieria Maszyn, 15(2010)1/2, 7-37.

[11] P. STĄCZEK, S. PŁASKA: Sterowanie uplastycznianiem preform w procesie wytwarzania pojemników z PET. Cz. II. Identyfikacja właściwości dynamicznych obiektu sterowania. Polimery, 58(2013)2, 121-126. 